\title{
THE IMPACT OF RELIGION ON VOTING BEHAVIOR
}

\section{Mian Gul Said $^{1^{*}}$, Aziz Ur Rahman ${ }^{2}$, Musab Yousufi ${ }^{3}$}

${ }^{1 *}$ Assistant Professor, Government College, Daggar, Buneer KP, Pakistan; ${ }^{2}$ Assistant Professor, Department of IR \& Political Science, Qurtuba University, Peshawar KP, Pakistan; ${ }^{3}$ Assistant Professor, Riphah Institute of Public Policy, Riphah International University, Islamabad, Pakistan.

Email: ${ }^{*}$ mgsaid80@gmail.com, ${ }^{2}$ aziz@qurtuba.edu.pk, ${ }^{3}$ musab_yousufi@live.com/musab.yousufi@riphah.edu.pk Article History: Received on $7^{\text {th }}$ January 2021, Revised on $2^{\text {nd }}$ March 2021, Published on $08^{\text {th }}$ March 2021

\section{Abstract}

Purpose: This study investigates the influence of religion on the voting behavior of the electorates of district Buner of Khyber Pakhtunkhwa in the 2013 general elections. The study empirically reveals the inclination of the people while considering religion as a determinant of voting behavior.

Methodology: Data for this work has been collected through a personally administered structured questionnaire. A sample representative size of 385 respondents was selected through a multi-stage-sample-method in a survey. SPSS (Statistical package for social sciences) version 21 has been used for the determination of P-value through the Chi-Square test.

Results: This investigation contended that voters consider religion as a significant determinant of voting behavior. They also support the participation of Ulama (religious scholars) in politics. Further, the study discovered that the majority of the electorates do not keep the religious affairs of the candidate in mind while making their choices. On polling day, the role of religion does not significantly affect the preferences of the people.

Applications: Results of the study shows that religion and voting behavior are interrelated. While analyzing electoral politics and voting choices, it is pertinent to consider the religion of the electorates.

Novelty/Originality: Electorates favor the role of religion in politics, but on polling day, majority voters do not care about religion.

Keywords: Voting Behavior, Elections, Religion, Electoral Politics, Chi-Square Test.

\section{INTRODUCTION}

Political participation is a fundamental human right throughout the world. Each person may take part in state affairs directly or indirectly. Based on the universal adult franchise, individuals express their assent through regular elections (Minority right group international, 2015). In democratic social orders, individuals choose their leaders to run the administration of the state. Voting offers an occasion for the electorates to perform the responsible job in the matters of the state. For political participation, using the choice to cast a vote in an election is the most recognized method (Flanigan, 1998). An election is a significant source of political socialization and participation. It makes a bridge between rulers and the common man (Encyclopaedia,2020). For a viable democracy, free and fair elections ought to be conducted regularly (Azhar, 2017). An election is the most noticeable component in the current majority rule system. It plays a crucial role in electing the right man for the right job to represent the electors' will, as the fear of re-election always pinches them. Representatives are, thus, chosen to frame future strategies of the state, keeping in view the popular will of the people. Therefore, to shape the future policies of their countries, an election is a controlling power invested in the hands of the people (Berganza,2000).

Voting behavior is whether qualified citizens cast votes and why they vote how they do (Hoene,2011). The study of voting behavior makes researchers capable to think about the sort of political framework and the nature of change. While examining voting behavior, the center is around how and why individuals settle on a specific electoral decision. Numerous determinants, for example, profession, ethnic character, gender, caste, age, religion, issues, party manifesto, election campaign, and credibility of the party leaders impact the democratic decisions of the electorates. These elements make the electoral behavior of the electorates. It makes them capable that to whom and in what direction they should cast a ballot. This electoral decision-making process is known as voting behavior (Elcock, 1976).

Different political scientists and sociologists have discussed the interaction of religion and politics. By and large, the contentions have been that of total or fractional interaction between the two phenomena (Laguda, 2008). All through the world, religion and politics are two imperative parts of human society. Religion addresses and conditions man's spiritual balance. Politics shapes the act of religion and figure out who gets what, when, and how in any given political setting (Lasswell, 1958). Human existence is profoundly impacted by religion. It has an extraordinary effect on each demonstration and attitude of a person particularly in developing countries like Pakistan. Religion is a prominent component of politics in Pakistan (Bashir,2019). The religious political parties use religious slogans and issues for getting votes. The role of religion is noticeable even in the most developed societies. America is a developed country yet the role of religion is obvious (Botterman, 2009). The predominant factor in the election of George W. Bush in America in 2000 and 2004 was his religious 
conservatism. He introduced himself as the primary heroin protecting the Christian faith against the fundamentalist Islamists (Wald, 2007) and (Greeley, 2004).

Religion was a solidifying power for Muslims in the sub-continent, assumed an essential job in the foundation of Pakistan. However, after the foundation of Pakistan, the role of religion became controversial. Different political parties came to the surface for getting electoral support on the nature of polity. Religious political parties began the battle for propagating their brand of ideas concerning the state (Binder, 1963). Before the 2002 election religious parties failed to get a considerable vote in any election. However, in the 2002 election religious parties under the banner of Muttahida Majlis-e-Amal (United Action Front) got the dominant part in Khyber Pakhtunkhwa (52 seats) and Balochistan (14 seats) (PILDAT, 2013) and (Election Commission of Pakistan, 2002). The alliance also succeeded in getting 59 seats in the National Assembly. This was a lion's share as compared with the past performance of the religious political parties (Wilder, 2005) and (Tanwir, 2002). The achievement of this alliance was for the most part because of military intervention in Afghanistan after the 9/11 assaults in America. The military intervention in Afghanistan was generally resented by the people of Pakistan and that of Khyber Pakhtunkhwa and Balochistan specifically. This feeling of hatred was promoted by MMA by introducing such a proclamation in which Shariah or Islamism was to a great extent featured. The motto of actualizing shariah chiefly pulled in the citizens and decided in favor of MMA. The current study is concerning the 2013 general elections and presents a different picture. This work contends that electorates look to religion as a significant determinant of voting behavior, yet while making choice the role of religion lessens. Notwithstanding, deciding on religious lines can't be ignored out rightly. Religion is still relevant in electoral decision-making.

\section{LITERATURE REVIEW}

Hoene (2011) examines diverse factors having an important role in molding the voting behavior of Asian Americans. These variables are gender, income, country of origin, and length of stay in the United States which significantly impacts one's choice to cast a ballot and interest in politics. The level of education is the greatest factor in voting behavior which was the basis of research. The conventional view that party familiarity develops at an early age, under the supervision of family and is generally unaffected by other political factors has been challenged by proof that grown-up partisanship is indeed very receptive to other political factors, for example, manifesto, retrospective evaluations, and voting in early elections (Franklin, 1984). The paper of (Raymond, 2011) argues that the religious-secular cleavage remained or has become a critical indicator of moderate vote decision.

Aden (2015) in his article examines the impact of political leaders on voting behavior. This study was undertaken in North Eastern Kenya. The investigation contends that style of leader, past role, and ability to convey message impact voting behavior. The investigation likewise infers that there is a huge connection between the character attributes of a leader with voting behavior. Madeley, J. (2002) elaborated in detail the religious factor in Scandinavian electoral politics. Berland Kaul,(2013) sheds light on urban voting behavior in India and investigates that why voters vote for the Bharatiya Janata Party (BJP). This study argues that ethnic interests and retrospective programmatic interests are significant factors in this regard.

Rose and Unwin (1969), Converse (1974), Rose (1974), Lijphart (1979), and Powell (1982) have stated that religion is assuming a huge role in deciding the political behavior of an individual. Brooks, Clem, and Jeff Manza (1997) dissected the connection between religion and voting in presidential elections in America. Brug, W.V.D. Hobolt, S. B. and Vreese, C.H.D. (2009) investigated religious voting in the election of Europe from 1989 to 2004 paints a more complex picture. It shows that the impact of religion has been declining, yet has expanded as of late, religion matters specifically for voting in favor of Christian Democratic groups and Conservative parties. In the study of Fox, Sandie Wightman, and James T. Richardson. (2001) findings show that religious connection was a superior indicator of legislative voting on abortion reform in comparison to other factors. Lijphart, A. (1979) investigated the general impact of the three conceivably most significant factors on voting behavior- social class, religion, and language-an examination of Belgium, Canada, South Africa, and Switzerland gives a "pivotal investigation". Among the three variables of party choice, religion arises as to the victor, language as a solid second place, and class as the third.

Ahmad, (2004) found that the caste system is by all accounts more grounded than a political affiliation in Pakistani politics. Kanwal, (2016) argue that family bond is more persuasive in voting behavior. The electors didn't give a lot of significance to the religious affairs of the competitor. Khan, F. K., \&Musarrat, R. (2014) in their work clarify the relationship of voting behavior with schooling, inner changes in a party, and barbarism. The examination inferred that the caste system is more grounded than political loyalty with respect to as inspiration for voting behavior is concerned. Muhammad Shakeel Ahmad (2010) in his Ph.D. thesis contends that family popularity of the competitor, helping the individuals in trouble, and biradari are affecting vote decisions. For citizens, national and provincial issues are less significant than local issues. Party identification was a significant determinant in voting behavior. Ahmed, M. (2012) argues that biradarism (casteism, 
tribalism) is the fundamental part of voting behavior. It has a profound effect on the political affiliation of the voters of Punjab.

Ishtiaq Ahmad and Muhammad Ishaq (2018) examined the significance of the party manifesto in the campaign strategy of the 2013 election. Lahore which is one of the educated urban areas in Pakistan, 52\% of the respondents didn't know even the meaning of the manifesto. Rather than a manifesto, reprimanding adversaries is a lot of viable devices in the political race. Farmanullah (2014) in his paper argues that voting based on religion is one of the determinants of voting behavior in Khyber Pakhtunkhwa. In any case, it isn't as significant as the casting vote based on issues and clientelism.

Hassan Shah (2019) is of the view that religion is a significant component in voting decisions in the Pakhtun society. Religion is assuming a vital job in making socio-political perspectives of the individuals. Religious parties used the slogans of execution of the Islamic system and that religious groups are the protectors of Islam. These slogans attracted a great number of electors in Khyber Pakhtunkhwa. Religious political parties exploited anti-Americanism in Khyber Pakhtunkhwa in the general election 2002 to attract the voters (Kizilbash, 1988). Athar (2002) stated that rising debt on Pakistan, poverty, and control of wealth in few hands may have isolated a segment of electorates from the major political parties and shifted loyalty to religious political parties. Upheld Athar's assessment and additionally depicted the rising help of the religious groups in Khyber Pakhtunkhwa as a response to the feudalism, and corruption of the secular parties.

\section{Research Questions}

1. To what extent it is important to vote on the promise of the promulgation of the Islamic system?

2. What should be the extent of the participation of Ulama (religious scholars) in politics?

3. To what extent you voted based on religion in the 2013 elections?

\section{METHODOLOGY}

The quantitative research technique was used to move toward the issue. Data has been gathered through a questionnaire from residents of district Buner of Khyber Pakhtunkhwa, Pakistan. Electoral lists of the Election Commission of Pakistan were utilized for the selection of respondents. SPSS version 21 has been used for the determination of P-value through the ChiSquare test.

\section{Research Population}

The population of the study is the enlisted male voters of district Buner. The reason to exclude female voters as respondents of the researcher was that they rarely take interest in elections and other political exercises. Because of social and religious constraints, it is hard for a male researcher to get to female respondents. As indicated by Election Commission of Pakistan statistics, the enlisted electors of the targeted area were 360019, out of which male enrolled voters were 195215 (Election Commission of Pakistan, 2013). The objective of choosing a small district was to focus on electoral decisions at the microlevel.

\section{Sample and Sampling Technique}

The research population of district Buner is more than 100,000 and as per Krejcie and Morgan, the total sample size becomes 385 (Krijcie, 1970). Hence to get a representative sample size, 385 citizens were chosen. This determination was made randomly based on a multi-stage sample technique which is as under:

Stage 1: There are 27 union councils in district Buner (Buner,n.d) and (Pakistan Bureau of Statistics. n.d.). In the first stage out of 27, 07 UCs were chosen randomly which were Chinglai, Nawagai, Rega, Batara, Krapa, Torwarsak, and Pir Baba. The choice of these union councils was done randomly, as all the union councils are rural in nature.

Stage 2: In the second stage 55 voters were chosen from every union council, making the complete 385 . Respondents were taken from the voter lists of the Election Commission of Pakistan based on random and systematic sampling techniques. Initial one elector was chosen randomly, and afterward, every fourth citizen was chosen till 55 respondents were finished from every union council. A significant number of respondents didn't return their questionnaire. A few respondents were hesitant and terrified to share their experience and information in written shape. Many were thinking about it as an exercise in futility and pointless action. Out of a total of 385 administered questionnaires, the researcher could get 306 appropriately filled and returned.

A close-ended questionnaire was used for this purpose since it is simple for respondents to reply and less tedious. The closed-ended questionnaire is additionally a more affordable survey technique. The ratio of responses in a structured questionnaire is higher than in an unstructured questionnaire. (Dawson, 2002). 


\section{RESULTS AND DISCUSSIONS}

This part contains results got through the poll. The information has been dissected through SPSS. The outcomes contain data got from the chosen respondents. Through Chi-Square Test and P-Value, the association of age, education, and profession has

been established with electoral decisions of the electorates of district Buner.

\section{Religion as a Voting Determinant}

Numerous studies have demonstrated the close connection between religion and governmental issues. (Huntington, 1993) had contended that religion is a predominant power driving worldwide politics after the cold war. (Fox, 2001) and (Philpott,2002) have concluded in the wake of examining the September 11, 2001 assaults in the United States that religion still plays a serious role in politics and society. Voting behavior is impacted by religion. The role of religion in conservative societies is more clear. The inquiries looked to evoke respondents' assessment on whether religion has any molding impact on their voting pattern. It likewise looked for respondents' answers on whether religion informed their voting pattern in the 2013 general elections in Buner. To pass judgment on the job of religion in voting behavior, various questions were asked from the respondents. The first question was, "To what extent it is important to vote on the promise of the promulgation of the Islamic system?" This inquiry was posed to know the overall view of the electorates seeing religion as a voting determinant. The reactions show that dominant part 209 (68.30\%) out of 306 upheld that electors should decide in favor of the said guarantee. Further, the question was analyzed in the light of several variables, like age, education, and profession of the electorates.

\section{Age Consideration}

The responses of various education groups have been given in the following table.

Table 1: Views in response to the question, "To what extent it is important to vote on the promise of the promulgation of the Islamic system?"

\begin{tabular}{llllll}
\hline & \multicolumn{4}{c}{ Age } & Total \\
\cline { 2 - 6 } & $\mathbf{1 8 - 3 0}$ Years & $\mathbf{3 1 - 4 0}$ Years & 41-50Years & Above 50 Years & \\
\hline \multirow{2}{*}{ To a great extent } & 76 & 59 & 41 & 33 & 209 \\
\cline { 2 - 6 } & $36.4 \%$ & $28.2 \%$ & $19.6 \%$ & $15.8 \%$ & $100.0 \%$ \\
\hline \multirow{2}{*}{ To some extent } & 12 & 16 & 14 & 8 & 50 \\
\cline { 2 - 6 } & $24.0 \%$ & $32.0 \%$ & $28.0 \%$ & $16.0 \%$ & $100.0 \%$ \\
\hline \multirow{2}{*}{ To a limited extent } & 3 & 9 & 7 & 4 & 23 \\
\cline { 2 - 6 } Not at all & $13.0 \%$ & $39.1 \%$ & $30.4 \%$ & $17.4 \%$ & $100.0 \%$ \\
\hline \multirow{2}{*}{ Total } & 6 & 11 & 5 & 2 & 24 \\
\hline & $25.0 \%$ & $45.8 \%$ & $20.8 \%$ & $8.3 \%$ & $100.0 \%$ \\
\hline
\end{tabular}

Chi square $=10.954$ p-value $=0.279$

As far as age, those having age 18-30 years (36.4\%), trailed by $31-40$ years $(28.2 \%), 41$ to 50 years (19.6\%), and above 50 years $(15.8 \%)$ upheld that a citizen should cast a ballot by and large on the guarantee of executing Islamic system. Among the individuals who contradicted to decide on the said guarantee, lion's share were the age group 31-40 years (45.8\%). They were trailed by $18-30$ years (25.0\%), $41-50$ years $(20.8 \%)$, and above 50 years $(8.3 \%)$.

The Chi-square test gives us an insignificant p-value. The value (0.279) is more than 0.05 , which shows that the age of the citizens has no role in their perspectives concerning casting a ballot projecting on the guarantee of executing the Islamic system.

\section{Education Consideration}

As clear from the table, a larger part of the respondents upheld that the electors should decide on the guarantee of executing the Islamic system. 
Table 2: Views in response to the question, "To what extent it is important to vote on the promise of the promulgation of the Islamic system?"

\begin{tabular}{lllllllll}
\hline & \multicolumn{9}{c}{ Education } & \multicolumn{3}{c}{ Total } \\
\cline { 2 - 10 } & Illiterate & Primary & Middle & Matric & Intermediate & Bachelor & Master & \\
\hline \multirow{2}{*}{ To a great extent } & 28 & 14 & 24 & 42 & 36 & 32 & 33 & 209 \\
\cline { 2 - 10 } & $13.4 \%$ & $6.7 \%$ & $11.5 \%$ & $20.1 \%$ & $17.2 \%$ & $15.3 \%$ & $15.8 \%$ & $100.0 \%$ \\
\multirow{2}{*}{ To some extent } & 5 & 9 & 6 & 7 & 8 & 5 & 10 & 50 \\
\cline { 2 - 10 } & $10.0 \%$ & $18.0 \%$ & $12.0 \%$ & $14.0 \%$ & $16.0 \%$ & $10.0 \%$ & $20.0 \%$ & $100.0 \%$ \\
\multirow{2}{*}{ To a limited extent } & 7 & 5 & 0 & 3 & 3 & 2 & 3 & 23 \\
\cline { 2 - 10 } & $30.4 \%$ & $21.7 \%$ & $0.0 \%$ & $13.0 \%$ & $13.0 \%$ & $8.7 \%$ & $13.0 \%$ & $100.0 \%$ \\
\multirow{2}{*}{ Not at all } & 4 & 3 & 3 & 2 & 6 & 2 & 4 & 24 \\
\cline { 2 - 9 } & $16.7 \%$ & $12.5 \%$ & $12.5 \%$ & $8.3 \%$ & $25.0 \%$ & $8.3 \%$ & $16.7 \%$ & $100.0 \%$ \\
\multirow{2}{*}{ Total } & 44 & 31 & 33 & 54 & 53 & 41 & 50 & 306 \\
\hline
\end{tabular}

Chi square $=22.504$ p-value $=0.210$

Those qualifying Matriculations were in dominant part (20.1\%), trailed by Intermediate (17.2\%), Master (15.8\%), Bachelor $(15.3 \%)$ and Illiterate $(13.4 \%)$ upheld to choose the guarantee of executing Islamic framework. The group opted for not at all, lion's share were Intermediate (25.0\%), trailed by Illiterate and Master (16.7\%), Primary and Middle (12.5\%), and Matric and Bachelor $(8.3 \%)$.

The Chi-square test gives an insignificant p-value. The value $(0.210)$ is more than 0.05 , which shows that the schooling of the electors has no job in their perspectives with respect to cast a ballot projecting on the guarantee of actualizing the Islamic system.

\section{Profession Consideration}

Reactions of various professions with respect to deciding on this line are in the accompanying table.

Table 3: Views in response to the question, "To what extent it is important to vote on the promise of the promulgation of the Islamic system?"

\begin{tabular}{|c|c|c|c|c|c|c|c|}
\hline & \multicolumn{6}{|c|}{ Profession } & \multirow[t]{2}{*}{ Total } \\
\hline & Servants & Farmers & Businessmen & Labour & Unemployed & Student & \\
\hline \multirow{2}{*}{ To a great extent } & 38 & 36 & 41 & 26 & 25 & 43 & 209 \\
\hline & $18.2 \%$ & $17.2 \%$ & $19.6 \%$ & $12.4 \%$ & $12.0 \%$ & $20.6 \%$ & $100.0 \%$ \\
\hline \multirow{2}{*}{ To some extent } & 10 & 9 & 8 & 15 & 2 & 6 & 50 \\
\hline & $20.0 \%$ & $18.0 \%$ & $16.0 \%$ & $30.0 \%$ & $4.0 \%$ & $12.0 \%$ & $100.0 \%$ \\
\hline \multirow{2}{*}{ To a limited extent } & 5 & 3 & 6 & 8 & 1 & 0 & 23 \\
\hline & $21.7 \%$ & $13.0 \%$ & $26.1 \%$ & $34.8 \%$ & $4.3 \%$ & $0.0 \%$ & $100.0 \%$ \\
\hline \multirow{2}{*}{ Not at all } & 4 & 4 & 6 & 5 & 2 & 3 & 24 \\
\hline & $16.7 \%$ & $16.7 \%$ & $25.0 \%$ & $20.8 \%$ & $8.3 \%$ & $12.5 \%$ & $100.0 \%$ \\
\hline \multirow{2}{*}{ Total } & 57 & 52 & 61 & 54 & 30 & 52 & 306 \\
\hline & $18.6 \%$ & $17.0 \%$ & $19.9 \%$ & $17.6 \%$ & $9.8 \%$ & $17.0 \%$ & $100.0 \%$ \\
\hline
\end{tabular}

Chi square $=23.101 \quad \mathrm{P}$ value $=0.082$

The category of students (20.6\%) trailed by businessmen (19.6\%), government servants $(18.2 \%)$, and farmers (17.2\%) upheld to decide on the guarantee of execution of the Islamic system. The voters who were against the statement, the greater part were from the category of businessmen $(25.0 \%)$, trailed by labor (20.8\%), servants and farmers (16.7\%), students $(12.5 \%)$, and jobless $(8.3 \%)$.

The Chi-square test gives an inconsequential p-value. The value (0.082) is more than 0.05 , which shows that the profession of the electors has no role in their perspectives with respect to cast a ballot projecting for the guarantee of execution of the Islamic system.

\section{Role of Ulama in Politics}

How people look to the participation of Ulama in governmental issues, is connected with religion as a determinant of voting decisions. In this regard, reactions were obtained concerning the inquiry, "What should be the degree of participation of 
Ulama (religious scholars) in politics? This was to decide that what electorates look like to the participation of Ulama in politics. A significant number, 207 (67.64\%) out of 306 were of the view that Ulama ought to participate in politics to a great extent. The inquiry was additionally investigated in the light of age, education, and profession of the electorates.

\section{Age Consideration}

As obvious from the accompanying table diverse age groups supported the role of Ulama in politics.

Table 4: Views in response to the question, "What should be the extent of participation of Ulama (religious scholars) in politics?"

\begin{tabular}{llllll}
\hline & \multicolumn{3}{c}{ Age } & Total \\
\cline { 2 - 6 } & $\mathbf{1 8 - 3 0}$ Years & $\mathbf{3 1 - 4 0}$ Years & $\mathbf{4 1 - 5 0 Y e a r s}$ & Above 50 Years & \\
\cline { 2 - 6 } To a great extent & 62 & 71 & 42 & 32 & 207 \\
\cline { 2 - 6 } & $30.0 \%$ & $34.3 \%$ & $20.3 \%$ & $15.5 \%$ & $100.0 \%$ \\
\hline \multirow{2}{*}{ To some extent } & 15 & 9 & 15 & 8 & 47 \\
\cline { 2 - 6 } & $31.9 \%$ & $19.1 \%$ & $31.9 \%$ & $17.0 \%$ & $100.0 \%$ \\
\hline \multirow{2}{*}{ To a limited extent } & 9 & 2 & 4 & 2 & 17 \\
\cline { 2 - 6 } & $52.9 \%$ & $11.8 \%$ & $23.5 \%$ & $11.8 \%$ & $100.0 \%$ \\
\hline \multirow{2}{*}{ Not at all } & 11 & 13 & 6 & 5 & 35 \\
\hline \multirow{2}{*}{ Total } & $31.4 \%$ & $37.1 \%$ & $17.1 \%$ & $14.3 \%$ & $100.0 \%$ \\
\hline
\end{tabular}

Chi square $=10.960$ p-value $=0.278$

As to age, those having the age group 31-40 were in majority (34.3\%), trailed by 18 to 30 years (30.0\%), 41-50 years (20.3\%), and those hailing from the category of over 50 years (15.5\%) communicated that Ulama should take part in politics to a great extent. The individuals who contradicted to support the participation of Ulama in governmental issues, dominant part were the age group 31-40 years (37.1\%). They were trailed by $18-30$ years $(31.4 \%), 41-50$ years $(17.1 \%)$, and above 50 years $(14.3 \%)$.

The Chi-square test gives an inconsequential p-value. The value (0.278) is more than 0.05 , which shows that the age of the electors has no role in their perspectives with respect to the participation of Ulama (religious scholars) in politics.

\section{Education Consideration}

Reactions of various education groups are given in the accompanying table.

Table 5: Views in response to the question, "What should be the extent of participation of Ulama (religious scholars) in politics?"

\begin{tabular}{lllllllll}
\hline & \multicolumn{6}{c}{ Education } & \multicolumn{3}{c}{ Total } \\
\cline { 2 - 10 } & Illiterate & Primary & Middle & Matric & Intermediate & Bachelor & Master & \\
\hline \multirow{2}{*}{ To a great extent } & 35 & 14 & 24 & 35 & 38 & 27 & 34 & 207 \\
\cline { 2 - 10 } & $16.9 \%$ & $6.8 \%$ & $11.6 \%$ & $16.9 \%$ & $18.4 \%$ & $13.0 \%$ & $16.4 \%$ & $100.0 \%$ \\
\hline \multirow{2}{*}{ To some extent } & 5 & 9 & 2 & 11 & 6 & 9 & 5 & 47 \\
\cline { 2 - 10 } & $10.6 \%$ & $19.1 \%$ & $4.3 \%$ & $23.4 \%$ & $12.8 \%$ & $19.1 \%$ & $10.6 \%$ & $100.0 \%$ \\
\hline \multirow{2}{*}{ To a limited extent } & 1 & 4 & 2 & 2 & 2 & 2 & 4 & 17 \\
\cline { 2 - 9 } & $5.9 \%$ & $23.5 \%$ & $11.8 \%$ & $11.8 \%$ & $11.8 \%$ & $11.8 \%$ & $23.5 \%$ & $100.0 \%$ \\
\hline \multirow{2}{*}{ Not at all } & 3 & 4 & 5 & 6 & 7 & 3 & 7 & 35 \\
\hline \multirow{2}{*}{ Total } & $8.6 \%$ & $11.4 \%$ & $14.3 \%$ & $17.1 \%$ & $20.0 \%$ & $8.6 \%$ & $20.0 \%$ & $100.0 \%$ \\
\hline
\end{tabular}

Chi square $=20.618$ p-value $=0.299$

With respect to education, it was discovered that Intermediate level qualified were in majority (18.4\%), trailed by Matriculate and Illiterate (16.9\%) each, Master degree holders (16.4\%) and Bachelor (13.0\%) communicated that Ulama should participate in politics to a great extent. The group decided for not at all, dominant part were Intermediate and Master (20.0\%) each, trailed by Matric (17.1\%), Middle (14.3\%), Primary (11.4\%), and Illiterate and Bachelor (8.6\%) each. 
The Chi-square test gives an insignificant p-value. The p-value (0.299) is more than 0.05 , which shows that the schooling of the citizens has no job in their perspectives with respect to the interest of Ulama (religious scholars) in politics.

\section{Profession Consideration}

How the voters of various professions look to the role of Ulama in politics, the detail is given in the table beneath.

Table 6: Views in response to the question, "What should be the extent of participation of Ulama (religious scholars) in politics?"

\begin{tabular}{|c|c|c|c|c|c|c|c|}
\hline & \multicolumn{6}{|c|}{ Profession } & \multirow{2}{*}{ Total } \\
\hline & Servants & Farmers & Businessmen & Labour & Unemployed & Student & \\
\hline \multirow{2}{*}{ To a great extent } & 42 & 32 & 46 & 31 & 24 & 32 & 207 \\
\hline & $20.3 \%$ & $15.5 \%$ & $22.2 \%$ & $15.0 \%$ & $11.6 \%$ & $15.5 \%$ & $100.0 \%$ \\
\hline \multirow{2}{*}{ To some extent } & 7 & 7 & 8 & 13 & 3 & 9 & 47 \\
\hline & $14.9 \%$ & $14.9 \%$ & $17.0 \%$ & $27.7 \%$ & $6.4 \%$ & $19.1 \%$ & $100.0 \%$ \\
\hline \multirow{2}{*}{ To a limited extent } & 2 & 2 & 1 & 7 & 1 & 4 & 17 \\
\hline & $11.8 \%$ & $11.8 \%$ & $5.9 \%$ & $41.2 \%$ & $5.9 \%$ & $23.5 \%$ & $100.0 \%$ \\
\hline \multirow{2}{*}{ Not at all } & 6 & 11 & 6 & 3 & 2 & 7 & 35 \\
\hline & $17.1 \%$ & $31.4 \%$ & $17.1 \%$ & $8.6 \%$ & $5.7 \%$ & $20.0 \%$ & $100.0 \%$ \\
\hline \multirow{2}{*}{ Total } & 57 & 52 & 61 & 54 & 30 & 52 & 306 \\
\hline & $18.6 \%$ & $17.0 \%$ & $19.9 \%$ & $17.6 \%$ & $9.8 \%$ & $17.0 \%$ & $100.0 \%$ \\
\hline
\end{tabular}

Chi square $=22.273 \quad \mathrm{P}$ value $=0.101$

Businessmen and shopkeepers were in larger part (22.2\%) who upheld the assertion. They were trailed by government servants $(20.3 \%)$, farmers and students $(15.5 \%)$ each, and unemployed (11.6\%) who communicated that Ulama should take part in politics to a great extent. The voters who were against the idea, larger part were from the gathering of farmers (31.4\%), trailed by students (20.0\%), servants and businessmen (17.1\%) each, labor (8.6\%), and jobless (5.7\%).

The Chi-square test gives an insignificant p-value. The p-value $(0.101)$ is greater than 0.05 , which shows that the profession of the citizens has no role in their perspectives with respect to the participation of Ulama (religious scholars) in politics.

\section{Religion as a Voting Determinant in 2013 Election}

After assessing general inquiry seeing religion as a voting determinant, a more explicit inquiry was posed. This inquiry was, "To what extent you voted on the basis of religion in the 2013 elections?" The intention was to judge the impact of religion in the voting choice of the electorates in the 2013 election. There was a blend reaction, as $114(37.25 \%)$ cast a ballot by and large while 109 (35.62\%) completely dismissed to decide on a strict premise. In contrast with the above two inquiries, here in a particular case, the rate dropped from $68.30 \%$ to $37.25 \%$. Further, this inquiry was dissected in the light of a few factors, such as age, education, and profession of the electorates.

\section{Age Consideration}

Age is a significant determinant of casting ballot choices. In the accompanying table, the reactions of various groups have been given.

Table 7: Views in response to the question, "To what extent you voted based on religion in the 2013 elections?"

\begin{tabular}{llllll}
\hline & \multicolumn{3}{c}{ Age } & \multicolumn{2}{c}{ Total } \\
\cline { 2 - 6 } & $\mathbf{1 8 - 3 0}$ Years & $\mathbf{3 1 - 4 0}$ Years & $\mathbf{4 1 - 5 0 Y e a r s}$ & Above 50 Years & \\
\hline \multirow{2}{*}{ To a great extent } & 38 & 35 & 21 & 20 & 114 \\
\cline { 2 - 6 } & $33.3 \%$ & $30.7 \%$ & $18.4 \%$ & $17.5 \%$ & $100.0 \%$ \\
\hline \multirow{2}{*}{ To some extent } & 16 & 19 & 7 & 12 & 54 \\
\cline { 2 - 6 } & $29.6 \%$ & $35.2 \%$ & $13.0 \%$ & $22.2 \%$ & $100.0 \%$ \\
\hline \multirow{2}{*}{ To a limited extent } & 8 & 12 & 5 & 4 & 29 \\
\cline { 2 - 6 } & $27.6 \%$ & $41.4 \%$ & $17.2 \%$ & $13.8 \%$ & $100.0 \%$ \\
\hline \multirow{2}{*}{ Not at all } & 35 & 29 & 34 & 11 & 109 \\
\hline \multirow{2}{*}{ Total } & $32.1 \%$ & $26.6 \%$ & $31.2 \%$ & $10.1 \%$ & $100.0 \%$ \\
\hline
\end{tabular}

Chi square $=13.533$ p-value $=0.140$ 
It was discovered that (33.3\%) of the group 18-30 years decided based on religion, while (32.1\%) of this group completely dismissed this idea. They were trailed by the group of 31-40 years (30.7\%) who decided in favor of religion, while (26.6\%) of this group declined to decide based on religion. (18.4\%) of the age group, 41 to 50 years cast a ballot, while (31.2\%) of this class declined to vote on the basis of religion.

The Chi-square test gives an unimportant p-value. The p-value $(0.140)$ is more than 0.05 , which shows that the age of the citizens has no role in the choice to decide on the basis of religion in the 2013 elections.

\section{Education Consideration}

As obvious from the P-value, there exists a close connection between age and deciding on religious lines.

Table 8: Views in response to the question, "To what extent you voted on the basis of religion in the 2013 elections?"

\begin{tabular}{lllllllll}
\hline & \multicolumn{9}{c}{ Education } & \multicolumn{2}{c}{ Total } \\
\cline { 2 - 10 } & Illiterate & Primary & Middle & Matric & Intermediate & Bachelor & Master & \\
\hline \multirow{2}{*}{ To a great extent } & 14 & 5 & 14 & 25 & 20 & 20 & 16 & 114 \\
\cline { 2 - 10 } & $12.3 \%$ & $4.4 \%$ & $12.3 \%$ & $21.9 \%$ & $17.5 \%$ & $17.5 \%$ & $14.0 \%$ & $100.0 \%$ \\
\hline \multirow{2}{*}{ To some extent } & 12 & 1 & 6 & 9 & 8 & 7 & 11 & 54 \\
\cline { 2 - 10 } & $22.2 \%$ & $1.9 \%$ & $11.1 \%$ & $16.7 \%$ & $14.8 \%$ & $13.0 \%$ & $20.4 \%$ & $100.0 \%$ \\
\hline \multirow{2}{*}{ To a limited extent } & 5 & 1 & 2 & 7 & 5 & 3 & 6 & 29 \\
\cline { 2 - 10 } & $17.2 \%$ & $3.4 \%$ & $6.9 \%$ & $24.1 \%$ & $17.2 \%$ & $10.3 \%$ & $20.7 \%$ & $100.0 \%$ \\
\hline \multirow{2}{*}{ Not at all } & 13 & 24 & 11 & 13 & 20 & 11 & 17 & 109 \\
\cline { 2 - 9 } & $11.9 \%$ & $22.0 \%$ & $10.1 \%$ & $11.9 \%$ & $18.3 \%$ & $10.1 \%$ & $15.6 \%$ & $100.0 \%$ \\
\hline \multirow{2}{*}{ Total } & 44 & 31 & 33 & 54 & 53 & 41 & 50 & 306 \\
\hline
\end{tabular}

Chi square $=35.862$ p-value $=0.007$

With respect to education, (21.9\%) of Matriculate decided in favor of religion, while (11.9\%) of the said group dismissed to decide in favor of religion. Those having Intermediate (17.5\%) cast a ballot, while (18.3\%) didn't decide in favor of religion. (17.5\%) of Bachelor's degree holders decided based on religion, while (10.1\%) of this class didn't decide on this base.

The Chi-square test gives an important p-value. The p-value (0.007) is smaller than 0.05 , which shows that the education of the electors has an incredible part in the choice to cast a ballot or not to decide on a religious basis in the 2013 election.

\section{Profession Consideration}

Reactions of various professions show the close connection between profession and casting votes on the basis of religion.

Table 9: Responses to the question, "To what extent you voted on the basis of religion in the 2013 elections?"

\begin{tabular}{|c|c|c|c|c|c|c|c|}
\hline & \multicolumn{6}{|c|}{ Profession } & \multirow[t]{2}{*}{ Total } \\
\hline & Servants & Farmers & Businessmen & Labour & Unemployed & Student & \\
\hline \multirow{2}{*}{ To a great extent } & 25 & 22 & 18 & 10 & 17 & 22 & 114 \\
\hline & $21.9 \%$ & $19.3 \%$ & $15.8 \%$ & $8.8 \%$ & $14.9 \%$ & $19.3 \%$ & $100.0 \%$ \\
\hline \multirow{2}{*}{ To some extent } & 13 & 14 & 6 & 10 & 3 & 8 & 54 \\
\hline & $24.1 \%$ & $25.9 \%$ & $11.1 \%$ & $18.5 \%$ & $5.6 \%$ & $14.8 \%$ & $100.0 \%$ \\
\hline \multirow{2}{*}{ To a limited extent } & 7 & 5 & 8 & 6 & 1 & 2 & 29 \\
\hline & $24.1 \%$ & $17.2 \%$ & $27.6 \%$ & $20.7 \%$ & $3.4 \%$ & $6.9 \%$ & $100.0 \%$ \\
\hline \multirow{2}{*}{ Not at all } & 12 & 11 & 29 & 28 & 9 & 20 & 109 \\
\hline & $11.0 \%$ & $10.1 \%$ & $26.6 \%$ & $25.7 \%$ & $8.3 \%$ & $18.3 \%$ & $100.0 \%$ \\
\hline \multirow{2}{*}{ Total } & 57 & 52 & 61 & 54 & 30 & 52 & 306 \\
\hline & $18.6 \%$ & $17.0 \%$ & $19.9 \%$ & $17.6 \%$ & $9.8 \%$ & $17.0 \%$ & $100.0 \%$ \\
\hline
\end{tabular}

Chi square $=34.833 \quad \mathrm{P}$ value $=0.003$

It was communicated that there is a more prominent relationship between the profession and deciding on a religious base. (21.9\%) of the government, servants cast vote, while (11.0\%) of this category didn't decide on this base. They were trailed by $(19.3 \%)$ of farmers who cast a ballot, while (10.1\%) didn't decide on a religious base. Among students (19.3\%) cast their vote, while (18.3\%) declined to decide on religion base in the 2013 elections. 
The Chi-square test gives an important p-value. The p-value (0.003) is smaller than 0.05, which shows that the profession of the electors has an incredible role in the choice to cast a vote or not to decide on the basis of religion in the 2013 general election.

\section{CONCLUSION}

The current investigation shows and analyzes the effects of religion on the electoral choices of the people of the district Buner of Khyber Pakhtunkhwa. Regarding the role of religion in affecting voting choices, the current study contends that electors consider the role of Ulama (religious scholars) in politics necessary. However, while making choices based on voting, the significance of religion vanishes. When citizens were asked to what extent it is important to vote on the promise of the promulgation of the Islamic system. The majority of the respondents, 209 out of $306(68.30 \%)$ completely agreed. Similarly, in response to the question, "What should be the extent of participation of Ulama (religious scholars) in politics? The information contends that a greater part of 207 (67.64\%) gives them a more prominent role in politics. To judge the role of religion as a determinant in the 2013 election, the voters were asked a particular question, "To what extent you voted because of religion in the 2013 elections?" The gathered information shows that 114 (37.25\%) voted based on religion. It shows that while making choices, citizens gave little significance to the religious affairs of the candidate. Despite that, the role of religion to influence voting behavior cannot be overlooked.

The study targeted male voters of district Buner. The reason to exclude female voters as respondents of the researcher was that they rarely take an interest in the election or any other political activities. Apart from this, social and religious constraints make it difficult for a male researcher to get to female respondents. Hence, the study suggests that future researches should focus on female electorates and their voting behavior regarding subsequent elections. A study should also be conducted in other parts of the country, as voting behavior is not static.

Over time, it gradually changes. Political consciousness, exposure to media, industrialization, urbanization, education, religious considerations, and other important local, national, and international issues change voting behavior. It is a dynamic process of absorbing new cultural patterns constantly. It makes electoral studies progressive and innovative for future exploration.

\section{AUTHORS' CONTRIBUTIONS}

Mian Gul Said is the primary author of this paper. This research paper is a part of his M.Phil thesis. He also conducted the survey and gathered the data for the research.

Dr. Aziz ur Rahman supervised and guided the primary author. He also helps in formulating the abstract and guided the authors in formulating the results and discussion.

Dr. Musab Yousufi has contributed to review the paper and the language of the paper. He also contributed to editing the paper and give directions to the authors regarding methodology and data analysis.

\section{ACKNOWLEDGMENT}

The authors have received no funding from any supporting or funding agency.

\section{.REFERENCES}

1. Aden, H. I. (2015). Effect of Political Leadership on Voting Behavior in North Eastern Kenya. Master thesis, The Management University of Africa. Retrieved from http://repository.mua.ac.ke/447

2. Ahmad, M. S. (2010). Electoral Politics in NWFP. 1988-1999. Doctoral dissertation, National Institute of Pakistan Studies QUAID-I-AZAM UNIVERSITY ISLAMABAD, Islamabad,2010.Retrieved from http://prr.hec.gov.pk /jspui/bitstream /123456789/1232/2/1159S.pdf

3. Ahmed, I., \&Ishaq, M. (2018). Manifestoes Importance in Election Campaign in 2013.

4. Ahmed, M. (2012). Voting behaviour in rural and urban areas of Punjab. Journal of Political Studies, 4556.Retrieved from http://pu.edu.pk/ images/journal /pols/Currentissuepdf/voting\%20 behaviour.pdf

5. Ahmad, M. (2004). Faisalabad Division keSiasat per BiradarismkayAsarat, Ph.D Thesis, Department of Political Science and International Relations, Multan,B.Z.University.p.46.

6. Athar, A. (2002). Moving in the Circle, The Nation, 18th October, Lahore, Pakistan.

7. Azhar, A. G. (2017). The Key to Triumphant Practices of Technology in Elections: It's Time to Reboot Electoral Process in Pakistan.

8. Bashir, U., \& Khalid, I. (2019). Religion and Electoral Politics in Punjab: A Case Study of 2018 General Elections.

9. Berganza, J. C. (2000). Politicians, voters and electoral processes: an overview. Investigaciones económicas, 24(3), 501-543. Retrieved from https:// www.redalyc.org /pdf/173/17324301.pdf 
10. BerlandKaul, A. (2013). Ethnic Politics and Urban Voting Behavior in India: Explaining Variation in Electoral Support for the Bharatiya Janata Party, 1999-2009. Retrieved from https://drum.lib.umd.edu/bitstream/handle/1903/14124/BerlandKaul_umd_011 E_14235

11. Binder, L. (1963). Religion and Politics in Pakistan. California: University of California Press.

12. Botterman, S. and Hooghe, M. (2009). The Christian Democratic Vote and Religious Belonging: The Relation between Religious Beliefs and Christian Democratic Voting and the Individual and Community Level in Belgium. 5 th General Conference of the European Consortium for Political Research, 10-12 September, https://lirias.kuleuven.be/bitstream/123456789/248076/1/26890-Botterman.pdf (Accessed 1st December, 2020)

13. Brooks, Clem and Jeff Manza. (1997). The religious factor in U.S. Presidential election 1960-1992. American Journal of Sociology, 103(1), 38-81. https://doi.org/10.1086/231171

14. Brug, W.V.D. Hobolt, S. B. and Vreese, C.H.D. (2009). Religion and Party Choice in Europe. West European Politics, Vol. 32, No. 6, 1266. https://doi.org/10.1080/01402380903230694

15. Buner-district-uc-wards-list-mna-mpa-seats-. $\quad$ (n.d.). Retrieved July 29, 2020, from https://www.politicpk.com/buner-district-uc-wards-list-mna-mpa-seats

16. Converse, P. E. (1974). Some Priority Variables in Comparative Electoral Research. pp. 727-45 in Electoral Behavior: A Comparative Handbook, edited by Richard Rose. New York: Free Press.

17. Dawson. Dr. C. (2002). Practical Research Methods, A User-friendly Guide to Mastering Research Techniques and Projects. Oxford: United Kingdom.

18. Elcock, Howard (1976). Political Behaviour. London: Methuen \& Co Ltd. pp. 217-218, 231,

19. Election Commission of Pakistan. (2013). Election Report Vol:11.pp.21,439. Retrieved from www.ecp.gov.pk/frmGenericPage.aspx?PageID=3053

20. Election Commission of Pakistan, (2002). Results of Provincial Assemblies 2002. https:// www.ecp.gov.pk/Documents/General\%20Election\%202002/Party\%20Position\%20A.Pdf (Accessed on 27/11/2020)

21. Encyclopedia Britannica Online. Retrieved from https://www.britannica. com/topic/ election-political-science on 24 December 2020.

22. Farmanullah. (2014). VOTING BEHAVIOUR IN PAKISTAN: (A Case Study of Khyber Pakhtunkhwa in 2008 General Elections). Pakistan Study Centre University of Peshawar. Retrieved from http://prr.hec.gov.pk /jspui/bitstream/ 123456789/2507/1/3060S.pdf

23. Flanigan, W. H. and Zingale, N.H. (1998). Political Behavior of the American Electorate. Edition (9), Washington DC: CQ Press.p.6.

24. Fox, J (2001). Religion: An oft-overlooked element of international studies. International Studies Review 3(3),5373. https://doi.org/10.1111/1521-9488.00244

25. Fox, Sandie Wightman and James T. Richardson. (2001). Religion and voting on abortion reform: A follow-up study. Journal for the Scientific Study of Religion, 14(2), 159-164. https://doi.org/10.2307/1384738

26. Franklin, C. H. (August 1984). Issue Preferences, Socialization, and the Evolution of Party Identification. American Journal of Political Science, 28(3), 459. https://doi.org/10.2307/2110900

27. Greeley, Andrew M. (2004, December). A Catholic vote. America, 191(18), 6. https://doi.org/10.1525/california/9780520238176.003.0016

28. Hoene, E. (2011). Asian Americans and politics: Voting behavior and political involvement. Senior thesis, Bemidji State University. Retrieved from https://www.bemidjistate.edu/academics/departments/political-science/wpcontent/uploads/sites/40/2015/ 05/

29. Huntington, SP (1993). The clash of civilizations? Foreign Affairs, 72 (3) Pp.22-49. https://doi.org/10.2307/20045621

30. Tanwir, F. (2002). Religious Parties and Politics in Pakistan. International Journal of Comparative Sociology, 43(3-5), 250-268. https://doi.org/10.1177/002071520204300303

31. Kanwal, L. S. (2016). Voting Behavior of Educated Youth in Pakistan: A Study of Multan City. Journal of the Research Society of Pakistan, 53(2).p.94,95,96. Retrieved from http://pu.edu.pk/images/journal/history/PDFFILES/6-Paper 53 2_ 16.pdf

32. Khan, F. K., \&Musarrat, R. (2014). Electoral Politics in Pakistan (Elections 2013): A Case Study of District Muzaffargarh. Journal of Public Administration and Governance, 4(4), 79-99. https://doi.org/10.5296/jpag.v4i4.6728

33. Khan, Imdad Ali. (1986). Voting Behaviour in Rural NWFP: A Study of People's Participation in Election. Peshawar: Pakistan Academy for Rural Development.

34. Kizilbash, H. H. (1988). Anti-Americanism in Pakistan, The Annals of the American Academy of Political and Social Science, 497, 58-67. https://doi.org/10.1177/0002716288497001005 
35. Krijcie, R. \&. (1970). Determining sample size for research activities. Educational and psychological measurement (Vol. 30).pp.607-610. https://doi.org/10.1177/001316447003000308

36. Laguda, D. O. (2008). Religion and politics in a pluralistic society: The Nigerian Experience. Politics and Religion Journal, 2(2), 123-133.

37. Lasswell, H. (1958). Politics: Who Gets What, When, and How. New York: Meridian Press.

38. Lijphart, A. (1979). Religious vs. Linguistic vs. Class Voting: The "Crucial Experiment" of Comparing Belgium, Canada, South Africa, and Switzerland. The American Political Science Review, Vol. 73, No. 2, 442-458. https://doi.org/10.2307/1954890

39. Madeley, J. (2002). Reading the Runes: The Religious Factor In Scandinavian Electoral Politics. Religion and Mass Electoral Behaviour in Europe, eds. David Broughton and Hans-Martien ten Napel, 40.

40. Minority right group international. (2015). Law and legal cases. Retrieved from Minority rights group international: http://minorityrights.org/law-and-legal-cases/universal-declaration-of-human-rights-article-21/ on 20 March 2020.

41. Pakistan Bureau of Statistics. (n.d.). district-glance-buner. Retrieved March, 2018, from http://www.pbs.gov.pk/content/district-glance-buner

42. Philpott, D (2002). The challenge of September 11 to secularism in international relations. World Politics. 55, pp. 66-95. https://doi.org/10.1353/wp.2003.0006

43. PILDAT. (2013). The first ten general elections of Pakistan. 1970 to 2013.pp.11,13,18,2 ,31,34,35,39,43. Retrieved from http:// www.PILDAT.org

44. Powell, G. B. (1982). Contemporary Democracies: Participation, Stability and Violence. Cambridge: Harvard University Press.

45. Raymond, C. (2011). The Continued Salience of Religious Voting in the United States, Germany, and Great Britain. Electoral Studies 30, 125-135. https://doi.org/10.1016/j.electstud.2010.10.001

46. Shah, H. (2019). Voting Behaviour in Pakistan: An Analysis of Partisan and Floating Voters in General Elections 2013 in Khyber Pakhtunkhwa (Doctoral dissertation, University of Peshawar, Peshawar.).

47. Rose, R. \& Unwin, D. (1969). Social Cohesion, Political Parties, and Strains in Regimes, Comparative Political Studies, 2, 7-67. https://doi.org/10.1177/001041406900200103

48. Rose, R. (1974). The Problem of Party Government. London: MacMillan. https://doi.org/10.1007/978-1-34901854-3

49. Tanwir, F. (2002). Religious parties and politics in Pakistan. International Journal of Comparative Sociology, 43(3-5), 250-268. https://doi.org/10.1177/002071520204300303

50. Wald, K.D. and Brown, A.C. (2007). Religion and Politics in the United States USA: Rowman\& Littlefield Publishers.

51. Wilder, A.R. (2005). Elections 2002: Legitimizing the Status Quo. Pakistan on the Brink: Politics, Economics, and Society, Craig Baxter, eds. Karachi: Oxford University Press. 